\title{
Chemical Composition and Therapeutic Effect of Mentha Species on Human Physiology
}

Irum Naureen ${ }^{1}$, Aisha Saleem ${ }^{*}$, Fabiha Sagheer ${ }^{2}$, Sadia Liaqat ${ }^{2}$, Sabiha Gull², Muqadas Fatima ${ }^{2}$, Zainab Arshad ${ }^{2}$

${ }^{1}$ Assistant Professor, School of Zoology, Minhaj University Lahore, Pakistan

${ }^{2}$ M. Phil Researcher, School of Zoology, Minhaj University Lahore, Pakistan

DOI: $10.36348 / \mathrm{sb} .2022 . v 08 \mathrm{i} 01.004$

| Received: 14.12.2021 | Accepted: 25.01.2022 | Published: 29.01 .2022

*Corresponding author: Aisha Saleem

Assistant Professor, School of Zoology, Minhaj University Lahore, Pakistan

\section{Abstract}

Plants are rich in phytochemical compounds that offer a source of dietary ingredients used to treat various ailments and problems. Among medicinal plants, mint (Mentha species) exhibits multiple health beneficial properties, such as prevention from cancer development and anti-obesity, antimicrobial, anti-inflammatory, anti-diabetic, and cardioprotective effects, as a result of its antioxidant potential, combined with low toxicity and high efficacy. Essential oils from mint have also been found to exert antibacterial activities. Using fresh mint and other herbs and spices in cooking can help a person add flavor while reducing their sodium and sugar intake.

Keywords: Mint, Mentha, medicine, phytochemicals, Antimicrobial, Anti-inflammatory, food preservation.

Copyright (C) 2022 The Author(s): This is an open-access article distributed under the terms of the Creative Commons Attribution 4.0 International License (CC BY-NC 4.0) which permits unrestricted use, distribution, and reproduction in any medium for non-commercial use provided the original author and source are credited.

\section{INTRODUCTION}

Herbs are a boon to traditional medicine practiced from ancient times. Plants are a potential source of traditional ayurvedic medicine, either in its natural form or processed have been used in curing many aliments. It provides a wide range of bioactive compounds present in different parts of plants that can be used for alternate therapy [1]. There are different plants of medicinal value but our interest lies on peppermint or commonly known as mint leaves.

Scientific Classification of Mint

\begin{tabular}{|l|l|}
\hline Kingdom & Plantae \\
\hline Phylum & Angiospermophyta \\
\hline Class & Magnoliopsida \\
\hline Order & Lamiales \\
\hline Family & Lamiaceae \\
\hline Genus & Mentha \\
\hline Species & 25 \\
\hline
\end{tabular}

Carl Linnaeus was renowned for first describing peppermint from plants and leaves in England during 1753 [2]. Mentha is derived from Greek word mintha [3], very commonly known as mint or peppermint. They are rarely yearly herbs aromatic and perennial [4]. It has almost 25 perennial species, belongs to the genus Mentha of the Lamiaceae family [5].
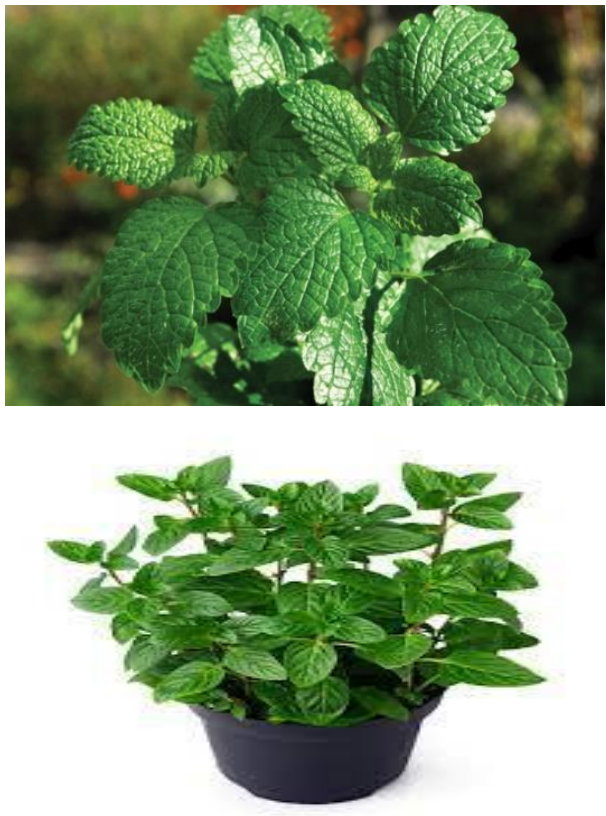

Fig 1: Mint Leaves, and Mint plant [6] 
Mint is a leafy plant that's perhaps best known for its association with fresh breath due to the cool sensation it creates in the mouth. Toothpaste, mouthwash, breath mints, and chewing gum are all commonly flavored with mint [5]. In addition to freshening breath, mint is also used to add flavor to foods and drinks. Mint is known for adding a fresh flavor to mint chocolate chip ice cream, mojito cocktails, and lamb dishes. It is distributed wildly and can be seen in almost all environmental conditions especially wet and moist soil [7]. It can also sustain sun heat and grows well even at this condition [8].

Throughout history, people have used different species of mint plants in medicine. Different types of mint plants offer a range of antioxidant qualities and potential health benefits, especially for people who have irritable bowel syndrome (IBS) [9].

Some Mentha species have common names, as listed in Table 1 [15-17]

\begin{tabular}{|c|c|}
\hline \multicolumn{2}{|c|}{ Some Mentha species have common names, as listed in Table 1 [15-17] } \\
\hline Scientific Name & Common Name \\
\hline M. aquatica L & Water mint \\
\hline M. piperita 'Lavandula' & Lavender mint \\
\hline M. arvensis L. & Corn mint, field mint, ginger mint, wild mint \\
\hline M. canadensis L & $\begin{array}{l}\text { American wild mint, Canada mint, Chinese mint, East Asian wild mint, Japanese mint, } \\
\text { Sakhalin mint }\end{array}$ \\
\hline M. longifolia L. & Himalayan silver mint, horsemint \\
\hline M. piperita L. & Peppermint \\
\hline M. piperita f. citrate & Bergamot mint, eau de cologne mint, orange mint \\
\hline M. pulegium & Mosquito plant, pennyroyal mint, Pennyrile, pudding grass, squaw mint \\
\hline M. spicata L. & Garden mint, homegrown mint, lamb mint, mackerel mint, spearmint \\
\hline M. suaveolens & Apple mint, pineapple mint, round-leafed mint, woolly mint \\
\hline M. suaveolens 'Variegata' & Pineapple mint \\
\hline M. x piperitaf. citrate 'Chocolate' & Chocolate mint \\
\hline
\end{tabular}

\section{Phytochemical Composition of Mentha}

Mentha species are rich in polyphenols [18] and, moreover, contain caffeic acid and its derivatives caftaric acid, cinnamic acid, ferulic acid, and oleanolic acid [19-21]. Flavonoids including luteolin and its derivatives apigenin, acacetin, diosmin, salvigenin and thymonin, have also been detected in these plants, accounting for some 10-70 compounds out of the total phenolics, and also flavanols such as catechin, epicatechin and coumarins, including esculetin and scopoletin [22-25]. With regard to mint compositions, the essential oils represent a major focus. They are colorless, pale yellow or greenish yellow [26] and alcohols, ketones, esters, ethers and oxides are their main components in Mentha species [27, 28].

Main chemical compounds isolated from different Mentha species is listed as

\begin{tabular}{|c|c|c|c|}
\hline $\begin{array}{l}\text { Species } \\
\text { Name }\end{array}$ & Essential Oil Components & Other Polyphenol Compounds & References \\
\hline M. aquatica L. & $\begin{array}{l}\text { epi-bicyclosesquiphellandrene, } 1,8 \text {-cineole, menthofuran, } \\
\beta \text {-caryophyllene, limonene, } p \text {-menthone, } \beta \text {-pinene, } \\
\text { germacrene } \mathrm{D}, \alpha \text {-pinene, } \alpha \text {-humulene, } \delta \text {-cadinene, } \\
\text { caryophyllene oxide, viridiflorol, viridiflorol epoxide II, } \alpha \text { - } \\
\text { cadinol, } \beta \text {-bisabolenol, } \alpha \text {-trans-bergamotene, p-cymene, } \\
\text { borneol, sabinene, } \beta \text {-myrcene, terpinyl acetate, eucalyptol }\end{array}$ & $\begin{array}{l}\text { Rosmarinus acid, lavandulifolioside, } \\
\text { rutin-O-glc, eriodictyol-O-rut, } \\
\text { quercetin-3-O-soph, verbascoside, } \\
\text { caffeic acid }\end{array}$ & {$[29-34]$} \\
\hline M. arvensis L. & $\begin{array}{l}\text { 3-Octanol, fenchone, endo-fenchol, p-menthone, iso- } \\
\text { menthone, neo-menthol, menthol, epi- } \\
\text { bicyclosesquiphellandrene, isopulegone, } 1 \text { - } \alpha \text {-terpineol, } \\
\text { pulegone, eugenol, cis-jasmone, } \beta \text {-bisabolene, cis-3- } \\
\text { hexenyl phenyl acetate, } \beta \text {-eudesmol, oxygenated } \\
\text { monoterpenes, } 1,8 \text {-cineole, } \beta \text {-caryophyllene oxide, linalyl } \\
\text { acetate, } \alpha \text {-phellandrene, terpinolene, limonene, pulegone }\end{array}$ & $\begin{array}{l}\text { Monogalactosyl diglycerides, } \\
\text { digalactosyldiglycerides, decyl } \\
\text { anhydride, 1-decanol }\end{array}$ & {$[17,33,34]$} \\
\hline $\begin{array}{l}\text { M.mozaffarian } \\
\text { L. }\end{array}$ & Piperitone, 1,8-cineol, linalool, $\alpha$-terpineol & $\begin{array}{l}\text { Piperitenone, pulegone, piperitenone } \\
\text { oxide, menthone, cis-piperitone } \\
\text { epoxide }\end{array}$ & [35-37] \\
\hline $\begin{array}{l}\text { M. pulegium } \\
\text { L. }\end{array}$ & $\begin{array}{l}\text { Piperitone, piperitenone, 4-terpineol, menthone, limonene, } \\
\text { naringenin, pulegone, iso-methane }\end{array}$ & $\begin{array}{l}\text { Rosmarinus acid, ellagic acid, } \\
\text { caffeic acid, caftaric acid, } \\
\text { chlorogenic acid, m-coumaric acid, } \\
\text { o-coumaric acid, p-coumaric acid, } \\
\text { crypto chlorogenic acid, } \\
\text { Isochlorogenic acid, neochlorogenic } \\
\text { acid, protocatechuic acid }\end{array}$ & {$[33,38,39]$} \\
\hline
\end{tabular}


Irum Naureen et al., Sch Bull, Jan, 2022; 8(1): 25-32

Mentha species are characterized by a great chemical diversity and were reported to contain a number of chemical compounds responsible for pharmacological properties (Table 3). The use of essential oils has a long history being widely exploited in the food, beverage, confectionery and cosmetic industries. In traditional Iranian medicine, it is reported that Mentha species have cooling sensation properties, strengthen the stomach and are effective to relieve digestive symptoms, respiratory tract problems and hemorrhoids [40].

Table 3: Chemical compounds in Mentha genus and their pharmacological properties

\begin{tabular}{|c|c|c|}
\hline $\begin{array}{l}\text { Pharmacological } \\
\text { Properties }\end{array}$ & Chemical Compounds Responsible for Pharmacological Properties & References \\
\hline Antioxidant & $\begin{array}{l}\text { Ascorbic acid, Rosmarinus acid, } \delta \text {-terpinene, } \alpha \text {-terpinene, p-cymene, } 1,8 \text {-cineole, cis- } \\
\text { carveol, carvone, Rosmarinus acid, cynaroside, cryptochlorogenic acid, naringin }\end{array}$ & {$[41,42,43]$} \\
\hline Antibacterial & $\begin{array}{l}\text { Luteolin, Rosmarinus acid, caffeic acid, gallocatechin, epigallocatechin gallate, } \\
\text { catechins, menthone, isomenthone, hexadecenoic acid, cis-carveol, carvone, limonene }\end{array}$ & {$[44,42,45]$} \\
\hline $\begin{array}{l}\text { Antifungal and } \\
\text { Anti Yeast }\end{array}$ & $\begin{array}{l}\text { Limonene, piperitenone oxide, menthol, menthone, carvone, cis-carveol and carvone, } \\
\text { piperitone, citronellal, caffeic acid, naringin, cryptochlorogenic acid, Rosmarinus acid }\end{array}$ & {$[42,44,46]$} \\
\hline Antiviral & Menthol, eriocitrin, Rosmarinus acid, luteolin 7-O-rutinoside, hesperidin, phytol & {$[44,47]$} \\
\hline Anticancer & $\begin{array}{l}\text { Eugenol, caryophyllene, t-cadinol, menthone, menthol crotonate, naringin, } \\
\text { cryptochlorogenic acid, rosmarinic acid }\end{array}$ & [48-50] \\
\hline
\end{tabular}

\section{HEALTH BENEFITS OF MINT LEAVES}

Mint may have several potential health benefits.Besides the traditional use of mint for culinary purposes and home remedies; it has the promising potential as a medicinal herb for treating complex medical ailments.

Medically benefits of various species of mint (Mentha spp.)

\begin{tabular}{|l|l|l|}
\hline Medical benefits & Species of mint & Preparation(s) used \\
\hline Antidiarrheal effect [51] & Mentha microphylla & Methanol extract \\
\hline Gastrointestinal antispasmodic [52] & Menthapiperita & Essential oil (peppermint oil) \\
\hline Antigiardial activity [53] & Menthapiperita & Methanolic, dichloromethane \&hexanic extracts \\
\hline Generalized bacterial infections [52] & Mentha piperita & Essential oil (peppermint oil) \\
\hline Antinociceptive effect [54] & Menthavillosa & Essential oil \\
\hline
\end{tabular}

\section{Nutritional composition and properties}

The Office of Dietary Supplements (ODS) advise that peppermint oil may cause skin irritation and redness Trusted Source. They recommend that parents or careers do not apply the ointment directly to the chest or face of a child due to serious possible side effects after direct inhalation.

Table 4: Nutritional composition and chemical value of leaves concentration per 100g [56]
\begin{tabular}{|l|l|}
\hline Nutrients & Chemical value (per 100 g) mint leaves concentration \\
\hline Moisture & $84.6 \%$ \\
\hline Ash & $1.6(\mathrm{~g})$ \\
\hline Protein & $4.1(\mathrm{~g})$ \\
\hline Carbohydrates & $5.60(\mathrm{~g})$ \\
\hline Calcium & $228(\mathrm{mg})$ \\
\hline Phosphorus & $61(\mathrm{mg})$ \\
\hline Iron & $15.4 \%$ \\
\hline Zinc & $0.42(\mathrm{mg})$ \\
\hline Vitamin C & $26(\mathrm{mg})$ \\
\hline
\end{tabular}

While mint contains several nutrients, the amount that a person would typically use in a meal is not sufficient to provide a significant amount of a person's daily requirement. Mint in the diet is most beneficial as a replacement for salty, sugary, or calorific flavorings. Mint ointments or supplements provide most of their benefits [8].

\section{Digestion}

Mint is a calming herb that people have used for thousands of years to help soothe an upset stomach or indigestion. The use of peppermint oil which in gastrointestinal conditions, including indigestion, IBS, stomach pain in children and feelings of sickness after surgery. Mint works against harmful microbes, regulates muscle relaxation, and helps control inflammation [8]. Mint may also be effective at relieving other digestive problems such as upset stomach and indigestion. Indigestion may occur when food sits in the stomach for too long before passing into the rest of the digestive tract. Food passes through the stomach quicker when people take peppermint oil with meals, which could relieve symptoms from this type of indigestion [9]. Mint is an effective treatment for 
nausea that often occurs in morning sickness. Eating a few mint leaves or smelling it every morning can help pregnant women prevent the nauseous feeling or cope with it better [10].

\section{Respiration}

Mint-flavored chewing gum and breath mints are some of the first things people reach for when trying to prevent or get rid of bad breath. Most of these products can mask foul-smelling breath for a few hours. However, they only cover up bad breath and don't reduce the bacteria or other compounds causing bad breath in the first place [24]. On the other hand, drinking peppermint tea and chewing on fresh leaves may be able to both mask bad breath and kill bacteria, as test-tube studies have highlighted the antibacterial effects of peppermint oil [9]. Regularly taking mint can ease chest congestion.

The methanol in mint acts as a decongestant, it helps loosen mucus collected in the lung and also shrinks swollen membranes in the nose to allow you to breathe easier. While using mint, make sure that you don't overdose it, otherwise, your air passage will become irritated [10].

\section{Brain Health}

Smelling the aroma of peppermint oil for five minutes prior to testing produced which are significant improvements in memory. Smelling these oils while driving increased alertness and decreased levels of frustration, anxiety and fatigue [58]. The peppermint oil could benefit brain function. The aroma of the oil was invigorating and led to less fatigue; it had no effect on brain function [9]. Mint contains menthol that can help relax muscles and ease the pain. Applying mint juice on your forehead and temples can give you relief from headache. Also, balms of mint base or mint oil are effective in curing headaches [10].

One of the main advantages of mint is that it is the most widely used herb in aromatherapy. Mint has a strong, refreshing smell that can ease stress and refresh the body and mind [57]. The apoptogenic activity of mint helps regulate the cortisol levels in the blood that triggers the body's natural response to ease the stress. Inhaling mint essential oil can instantly release serotonin in the blood which is a neurotransmitter that is well known for easing symptoms of stress and depression [10].

\section{Anti-cancer Activity}

Mint contains perillyl alcohol, which has been shown in lab studies to inhibit the growth of cancer cells, according to the AICR. Mint may also help to reduce digestive issues, something many cancer patients deal with in the midst of treatment. "Mint tea or mint candy may help some cancer patients reduce their nausea $[12,13]$.

\section{Cardiovascular Activity}

Mental stress can lead to arterial thrombotic events. Therefore, in the developed world, utmost attention is given to the prevention of thrombovascular disorders [54]. For this purpose, immense focus is directed on following a diet plan comprising food with antithrombotic effects, as regular consumption of such a diet provides an easy and controlling way of protection from cardiovascular diseases. In folk medicine therefore the application of Mentha $\mathrm{x}$ villosa as an antispasmodic has been justified because of its myorelaxant activity [55].

\section{Muscle pain Relief}

Peppermint oil acts as a natural painkiller and muscle relaxer. It's super helpful when it comes to comforting aching backs and sore muscles [14].

\section{Skin Health}

Mint has anti-inflammatory and anti-bacterial properties that help treat acne and pimple on the skin. Mint leaves contain a high amount of salicylic acid which acts as anti-acne. It also acts as an effective skin cleanser. Mint has antioxidant properties that help you get clean and youthful skin by removing free-radicals from the body [14]. Other ways mint makes your skin healthy is that it retains the moisture in the skin, clear off dead skin cells, and dirt from the skin pores, and makes the skin look radiant and toned [10]. Mint plants contain an antioxidant and anti-inflammatory agent called rosmarinic acid. Rosmarinic acid reduced symptoms of asthma when compared to a control group that did not receive a supplement [9]. The mint plant family provides a range of plant compounds that have anti-allergenic effects. However, the content of mint extract in oils and ointments may be far stronger than dietary mint. There is very little research into the effect of dietary mint on the symptoms of allergies [8].

\section{Oral Health}

Chewing mint leaves is a great way to improve oral hygiene and dental health. The essential oils in mint can help you get fresh breath. Also, using the mouthwash containing peppermint oil can help you kill bacteria in the mouth and provide you with healthy gums and teeth [11].

\section{Weight loss}

The aromatic herb mint could help you in weight loss. The essential oils of mint stimulate digestive enzymes to increase the bile flow and promote digestion. It also helps in improved nutrient absorption from the food. When the body is able to assimilate and absorb nutrients properly, your metabolism increases. The increase in metabolism promotes weight loss [59]. 


\section{Common cold}

Mint contains menthol. This is an aromatic decongestant that might help to break up phlegm and mucus, making it easier to expel. Applying menthol ointments or vapor rubs may be a safe and effective Trusted Source treatment for children who have a common cold. However, the American Lung Association (ALA) advises that scientific studies do not support the use of menthol for managing cold symptoms. Despite this, some people may find that cold symptoms reduceafter applying a menthol vapor rub [60].

\section{Diet}

We can easily add mint to green salads, desserts, smoothies and even water. The health benefits of mint didn't involve eating the leaves with food. Instead, mint was taken as a capsule, applied to the skin or inhaled via aromatherapy. The list below should help summarize some of the research discussed above.
Eating fresh or dried leaves used to treat bad breath. Inhaling essential oils May improve brain function and cold symptoms. Applying it to the skin used to reduce nipple pain from breastfeeding. Taking capsules with food may help to treat IBS and indigestion $[10,60]$.

\section{Antioxidant Property}

There is increasing interest in the utilization of plant-based natural antioxidants due to their safer nature and medicinal benefits compared to synthetic formulations. In this regard, extracts and essential oils (EOs) from many medicinal and food herbs have been investigated as promising source of effective antioxidant agents [62]. Mentha genus, contain high levels of antioxidants including phenolic compounds, ascorbic acid and carotenoids that can delay or inhibit the oxidation of different molecules. Mentha species, given their significant antioxidant activities, can be confidently used in pharmaceuticals, food and cosmetic productions.

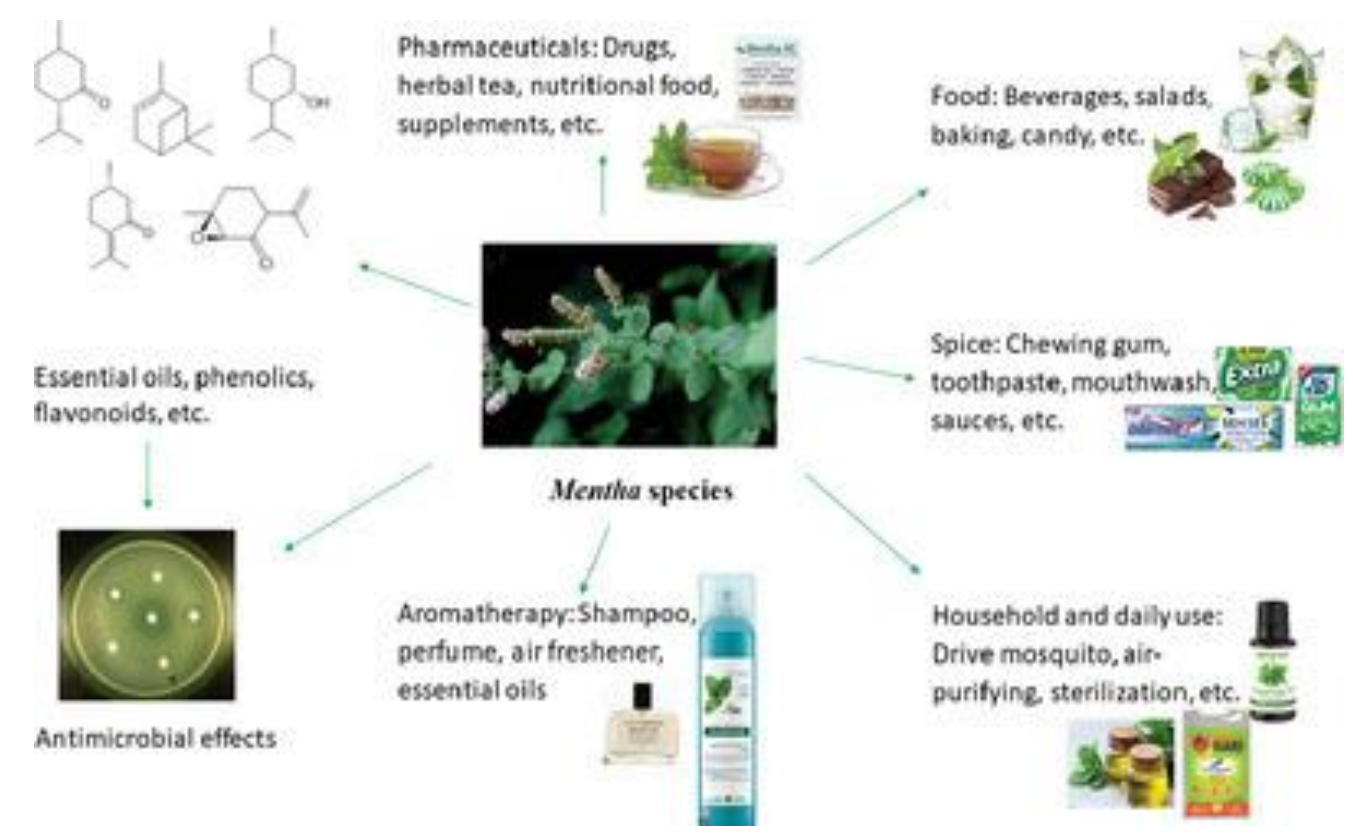

Fig 2: Summary of the main effect of Mentha species [61]

\section{CONCLUSION}

Mentha species have been used in indigenous medicine for many centuries and this review attempts to provide an overview on Mentha species' preventive and curative effects. The essential oils derived from Mentha species acts as a good expectorant and further have been used as a folk remedy for respiratory diseases such as bronchitis, sinusitis, tuberculosis and the common cold. However, numerous preclinical works have been performed, underlining the antioxidant, antibacterial, antifungal, anti-yeast, antiviral, and anticancer activity. Indeed, Mentha species, and especially essential oils, are used to reduce microbial load, suggesting a strong bactericidal, veridical, and fungicidal activity.

\section{REFERENCES}

1. Pramila, D. M., Xavier, R., Marimuthu, K., Kathiresan, S., Khoo, M. L., Senthilkumar, M., Sathya, K., \& Sreeramanan, S. (2012). The value of Plants used in traditional medicine for drug discovery. Journal of Medicinal Plants Research, 2, 331-335.

2. Park, Y. J., Baek, S. A., Choi, Y., Kim, J. K., \& Park, S. U. (2019). Metabolic Profiling of Nine Mentha Species and Prediction of Their Antioxidant Properties Using Chemometrics. Molecules, 24, 258-259.

3. Aflatuni, A., Uusitalo, J., Ek, S., \& Hohtola, A. (2005). Variation in the amount of yield and in the extract composition between conventionally produced and micropropagated peppermint and 
Irum Naureen et al., Sch Bull, Jan, 2022; 8(1): 25-32

spearmint. Journal of Essential Oil Research, 17(1), 66-70.

4. Lawrence, B. M. (2006). The Genus Mentha; CRC Press: Boca Raton, FL, US, 22, 1-56.

5. Brickell, S., Christopher, H., Cole, T. (2002). The American Horticultural Society, Encyclopedia of Plants \& Flowers. New York, NY, USA: DK Publishing, 6, 5-10.

6. Shaikh, S., Bin Yaacob, H., \& Rahim, Z. H. A. (2014) Prospective Role in Treatment of Major Illnesses and Potential Benefits as A Safe Insecticide and Natural Food Preservative of Mint (Mentha spp.): A Review Asian J Biomed Pharm Sci, 4, 1-12.

7. Benedec, D., Vlase, L., Oniga, I., \& Mot, A. C. (2013). Silaghi-Dumitrescu, R.; Hanganu, D.; Tiperciuc, B.; Cris san, G. LC-MS analysis and antioxidant activity of phenolic compounds from two indigenous species of mentha. Farmacia, 61, 262-267.

8. Taamalli, A., Arráez-Román, D., Abaza, L., Iswaldi, I., Fernández-Gutiérrez, A., Zarrouk, M., \& Segura-Carretero, A. (2015). LC-MS-based metabolite profiling of methanolic extracts from the medicinal and aromatic species Mentha pulegium and Origanum majorana. Phytochemical analysis, 26(5), 320-330.

9. Ait-Ouazzou, A., Lorán, S., Arakrak, A., Laglaoui, A., Rota, C., Herrera, A., ... \& Conchello, P. (2012). Evaluation of the chemical composition and antimicrobial activity of Mentha pulegium, Juniperus phoenicea, and Cyperus longus essential oils from Morocco. Food Research International, 45(1), 313-319.

10. Al-Sabahi, J. N., Hanif, M. A., Al-Maskari, A. Y., Al Busaidi, M. S. M., Al-Maskari, M. Y., \& AlHaddabi, M. H. (2016). Chemical report on wild growing Mentha arvensis and Citrullus colocynthus from Oman. Journal of Essential Oil Bearing Plants, 19(3), 719-726.

11. Andro, A. R., Boz, I., Zamfirache, M. M., \& Burzo, I. (2013). Chemical composition of essential oils from Mentha aquatica L. at different moments of the ontogenetic cycle. Journal of Medicinal Plants Research, 7(9), 470-473.

12. Anwar, F., Abbas, A., Mehmood, T., Gilani, A.-H., \& Rehman, N. (2019). Mentha: A genus rich in vital nutrient, A review. Phytotherapy Research, 33, 2548- 2570

13. Babar, A., Ali, A.-W. N., Saiba, S., Aftab, A., Alam, K. S., \& Firoz, A. (2015). Essential oils used in aromatherapy: A systemic review. Asian Pacific Journal of Tropical Biomedicine, 5(8), 601611.

14. Boukhebti, H., Chaker, A. N., Belhadj, H., Sahli, F., Ramdhani, M., Laouer, H., \& Harzallah, D. (2011). Chemical composition and antibacterial activity of Mentha pulegium L. and Mentha spicata L. essential oils. Pharmacia Lettre, 3, $267-$ 275.

15. Park, Y. J., Baek, S. A., Choi, Y., Kim, J. K., \& Park, S. U. (2019). Metabolic Profiling of Nine Mentha Species and Prediction of Their Antioxidant Properties Using Chemometrics. Molecules, 24, 258.

16. Gracindo, L. A. M. B., Grisi, M. C. M., Silva, D. B., Alvez, R. B. N., Bizzo, H. R., \& Vieira, R. F. (2006) Chemical characterization of mint (Mentha spp.) germplasm at Federal District, Brazil. Rev Bras dePla Med, 8, 5-9.

17. Barros, A. D. S., Morais, S. M. D., Ferreira, P. A. T., Vieira, Í. G. P., Craveiro, A. A., Fontenelle, R. O. D. S., Menezes, J. E. S. A. D., Silva, F. W. F. D., \& Sousa, H. A. D. (2015). Chemical composition and functional properties of essential oils from Mentha species. Ind Cro and Prod, 76, 557-564.

18. Pereira, O. R., \& Cardoso, S. M. (2013). Overview on Mentha and Thymus Polyphenols. Cur. Anal. Chem, 9, 382-396.

19. Benedec, D., Vlase, L., Oniga, I., Mot, A. C., Silaghi-Dumitrescu, R., Hanganu, D., Tiperciuc, B., \& Cri san, G. (2013). LC-MS analysis and antioxidant activity of phenolic compounds from two indigenous species of mentha. Farmacia, 61, 262-267.

20. Taamalli, A., Arráez-Román, D., Abaza, L., Iswaldi, I., Fernandez-Gutierrez, A., Zarrouk, M., \& SeguraCarretero, A. (2015). LC-MS-based metabolite profiling of methanolic extracts from the medicinal and aromatic species Menthapulegium and Origanummajorana. Phytochem Anal, 26, 320-330.

21. Wu, Z., Tan, B., Liu, Y., Dunn, J., Guerola, P.M., Tortajada, M., Cao, Z., \& Ji, P. (2019) Chemical Composition and Antioxidant Properties of Essential Oils from Peppermint, Native Spearmint and Scotch Spearmint. Molecules, 24, 2825-2827

22. Kosar, M., Dorman, H. J. D., Baser, K. H. C., \& Hiltunen, R. (2004). Screening of Free Radical Scavenging Compounds in Water Extracts of Mentha Samples Using a Postcolumn Derivatization Method. J Agric Food Chem, 52, 5004-5010.

23. Bimakr, M., Rahman, R. A., Taip, F. S., Ganjloo, A., Salleh, L. M., Selamat, J., Hamid, A., \& Zaidul, I. (2011). Comparison of different extraction methods for the extraction of major bioactive flavonoid compounds from spearmint (Menthaspicata L.) leaves. Food Bioprod. Process, 89, 67-72.

24. Salin, O., Törmäkangas, L., Leinonen, M., Saario, E., Hagström, M., Ketola, R. A., Saikku, P., Vuorela, H., \& Vuorela, P. M. (2011). Corn Mint (Menthaarvensis) Extract Diminishes Acute Chlamydia pneumoniae Infection in Vitro and in Vivo. J. Agric. Food Chem, 59, 12836-12842. 
Irum Naureen et al., Sch Bull, Jan, 2022; 8(1): 25-32

25. Fatiha, B., Didier, H. M., Naima, G., Khodir, M., Martin, K., Léocadie, K., Caroline, S., Mohamed, C., \& Pierre, D. (2015). Phenolic composition, in vitro antioxidant effects and tyrosinase inhibitory activity of three Algerian Mentha species: M. spicata (L.), M. pulegium (L.) and M. rotundifolia (L.) Huds (Lamiaceae). Ind Crop Prod, 74, 722730.

26. Franz, C., \& Novak, J. (2010). Sources of Essential Oils; CRC Press/Taylor \& Francis Group: Boca Raton, FL, USA, 6, 45-67.

27. Malingré, T. M. (1971). Chemotaxonomic study of Menthaarvensis L. Pharm. Week, 106, 165-171.

28. Shaikh, H., Yaacob, H., \& Rahim, Z. H. A. (2014). Prospective Role in Treatment of Major Illnesses and Potential Benefits as a Safe Insecticide and Natural Food Preservative of Mint (Mentha spp.): A Review. Asian J Biomed Pharm. Sci, 4, 1-12.

29. Andro, A. R., Boz, I., Zamfirache, M. M., \& Burzo, I. (2013). Chemical composition of essential oils from Menthaaquatica L. at different moments of the ontogenetic cycle. J Med Plant Res. 7: 470473.

30. Dai, D. N., Thang, T. D., Emmanuel, E. E., Abdulkabir, O. O., \& Ogunwande, I. A. (2015). Study on essential oil of Menthaaquatica L. from Vietnam. Am J Essent Oil, 2, 12-16.

31. Getahun, Z., Asres, K., Mazumder, A., \& Bucar, F. (2008). Essential Oil Composition, Antibacterial and Antioxidant Activities of Menthaaquatica Growing in Ethiopia. Ethiop Pharm. J, 26, 9-16.

32. Morteza-Semnani, K., Saeedi, M., \& Akbarzadeh, M. (2006). The Essential Oil Composition of Menthaaquatica L. J Essent Plants, 9, 283-286.

33. Fancello, F., Zara, S., Petretto, G. L., Chessa, M., Addis, R., Rourke, J. P., \& Pintore, G. (2017). Essential oils from three species of Mentha harvested in Sardinia: Chemical characterization and evaluation of their biological activity. Int $J$ Food Prop, 20, 1-11.

34. Pereira, O. R., Macias, R. I., Domingues, M. R., Marin, J. J., \& Cardoso, S. M. (2019). Hepatoprotection of Mentha aquatica L., Lavandula dentata L. and Leonurus cardiaca L. Antioxidants, 8(8), 267.

35. Shelepova, O. V., Voronkova, T. V., Kondrat'eva, V. V., Semenova, M. V., Bidyukova, G. F., \& Olehnovich, L. S. (2014). Phenotypic and phytochemical differences between Mentha arvensis L. and Mentha canadiensis L. Biology Bulletin, 41(1), 19-23.

36. Baban, S. T. (2016). Phytochemical and pharmacological review of Mentha arvensis. International Journal of Green Pharmacy, 10(2), 71-76.

37. Abdel-Hameed, E. S. S., Salman, M. S., Fadl, M. A., Elkhateeb, A., \& Hassan, M. M. (2018). Chemical composition and biological activity of Mentha longifolia L. essential oil growing in taif,
KSA extracted by hydrodistillation, solvent free microwave and microwave hydrodistillation. Journal of Essential Oil Bearing Plants, 21(1), 1-14.

38. Goudjil, M. B., Ladjel, S., Bencheikh, S. E., Zighmi, S., \& Hamada, D. (2015). Chemical composition, antibacterial and antioxidant activities of the essential oil extracted from the Mentha piperita of southern Algeria. Research Journal of Phytochemistry, 9(2), 79-87.

39. Marwa, C., Fikri-Benbrahim, K., Ou-Yahia, D., \& Farah, A. (2017). African peppermint (Menthapiperita) from Morocco: Chemical composition and antimicrobial properties of essential oil. J Adv Pharm Technol Res, 8, 86-90.

40. Kee, L. A., Shori, A. B., \& Baba, A. S. (2017) Bioactivity and health effects of Mentha spicata. Integr Food Nutr. Metab, 5, 1-2.

41. Bardaweel S. K., Bakchiche, B., Alsalamat, H. A., Rezzoug, M., Gherib, A., \& Flamini, G. (2018). Chemical composition, antioxidant, antimicrobial and Antiproliferative activities of essential oil of Menthaspicata L. (Lamiaceae) from Algerian Saharan atlas. BMC Complement Altern Med. 18, $1-7$.

42. Hussain, A.I., Anwar, F., Shahid, M., Ashraf, M., \& Przybylski, R. (2010). Chemical Composition, and Antioxidant and Antimicrobial Activities of Essential Oil of Spearmint (Menthaspicata L.) $J$ Essent Oil Res, 22, 78-84.

43. Al-Okbi, S. Y., Fadel, H. H., \& Mohamed, D. A. (2015). Phytochemical constituents, antioxidant and anticancer activity of Menthacitrata and Menthalongifolia. Res J Pharm. Biol Chem, 6, 739-751.

44. Anwar, F., Abbas, A., Mehmood, T., Gilani, A. H., \& Rehman, N. U. (2019). Mentha: A genus rich in vital nutra-pharmaceuticals-A review. Phytother Res, 33, 2548-2570.

45. Shahbazi, Y. (2015). Chemical Composition and In Vitro Antibacterial Activity of Menthaspicata Essential Oil against Common Food-Borne Pathogenic Bacteria. J Pathog, 1-5.

46. Barros, A. D. S., De Morais, S. M., Ferreira, P. A. T., Vieira, I. G. P., Craveiro, A. A., Fontenelle, R. O. D. S., De Menezes, J. E. S. A., Da Silva, F. W. F., \& De Sousa, H. A. (2015). Chemical composition and functional properties of essential oils from Mentha species. Ind Crop Prod, 76, 557564.

47. Li, Y., Liu, Y., Ma, A., Bao, Y., Wang, M., \& Sun, Z. (2017). In vitro antiviral, anti-inflammatory, and antioxidant activities of the ethanol extract of Menthapiperita L. Food Sci Biotechnol, 26, 16751683.

48. Elansary, H. O., Szopa, A., Kubica, P., Ekiert, H., Klimek-Szczykutowicz, M., El-Ansary, D. O., \& Mahmoud, E. A. (2020). Polyphenol Profile and Antimicrobial and Cytotoxic Activities of Natural 
Mentha $\times$ piperita and Menthalongifolia Populations in Northern Saudi Arabia. Processes, 8, 479 .

49. Yassin, M. T., Mostafa, A. A., \& Al-Askar, A. A. (2020). Anticandidal and anti-carcinogenic activities of Menthalongifolia (Wild Mint) extracts in vitro. J King Saud Univ.-Sci, 32, 2046-2052.

50. Kee, L. A., Shori, A. B., \& Baba, A. S. (2017). Bioactivity and health effects of Mentha spicata. Integr Food Nutr Metab, 5, 1-2.

51. Atta, A. H., \& Mouneir, S. M. (2004). Antidiarrheal activity of some Egyptian medicinal plant extracts. J Ethnopharmacol, 92, 303-309. http://dx.doi.org/10.1016/j.jep.2004.03.017

52. Rodriguez-Fragoso, L., Reyes-Esparza, J., Burchiel, S.W., Herrera Ruiz, D., \& Torres, E. (2008). Risks and benefits of commonly used herbal medicine in Mexico. Toxicol Appl Pharm, 227 , 125-135. http://dx.doi.org/10.1016/j.taap.2007.10.005

53. Vidal, F., Vidal, J. C., Gadelha, A. P. R., Lopes, C. S., Coelho, M. G. P., \& Monteiro-Leal, L. H. (2007). Giardia lamblia: the effects of extracts and fractions from Mentha x piperita Lin.(Lamiaceae) on trophozoites. Experimental parasitology, 115(1), 25-31.

54. Atta, A. H., \& Abo EL- Sooud, K. (2004). The antinociceptive effect of some Egyptian medicinal plant extracts. J. Ethnopharmacol, 95, 235-238.

55. Lahlou, S., Carneiro-Leão, R. F. L., \& LealCardoso, J. H. (2002). Cardiovascular effects of the essential oil of Mentha $\mathrm{x}$ villosa in DOCAsalthypertensive rats. Phytomedicine, 9, 715-720.
56. Chouhan, S., Sharma, K., \& Guleria, S. (2017). Antimicrobial activity of some essential oils-present status and future perspectives: Medicines, 4(3), 58.

57. Chauhan, R. S., Nautiyal, M. C., \& Tava, A. (2010). Essential oil composition from aerial parts of Mentha spicata L. Journal of Essential Oil Bearing Plants, 13, 353-356.

58. Anwar, F., Abbas, A., Mehmood, T., Gilani, A. H., \& Rehman, N. U. (2019). Mentha: A genus rich in vital nutra-pharmaceuticals $A$ review. Phytother Res, 33, 2548-2570.

59. Petrovska, B. B. (2012). Historical review of medicinal plants' usage. Pharmacognosy reviews, 6(11), 1-5.

60. Šari'c-Kundali'c, B., Fialová, S., Dobeš, C., Ölzant, S., Tekel'ová, D., Gran`ai, D., Reznicek, G., \& Saukel, J. (2009). Multi variate numerical taxonomy of Mentha species, hybrids, varieties and cultivars. Sci Pharm, 77, 851-876.

61. Abdelli, M., Moghrani, H., Aboun, A., \& Maachi, R. (2016). Algerian Mentha pulegium L. leaves essential oil: Chemical composition, antimicrobial, insecticidal and antioxidant activities: Industrial Crops and Products, 94, 197-205.

62. Goudjil, M. B., Ladjel, S., Bencheikh, S. E., Zighmi, S., \& Hamada, D. (2015). Chemical composition, antibacterial and antioxidant activities of the essential oil extracted from the Mentha piperita of Southern Algeria. Research Journal of Phytochemistry, 9, 79-87. 